\title{
JPCS
}

Peqguruang: Conference Series

Vol. 3 No. 2 Nov. 2021

elSSN: 2686-3472

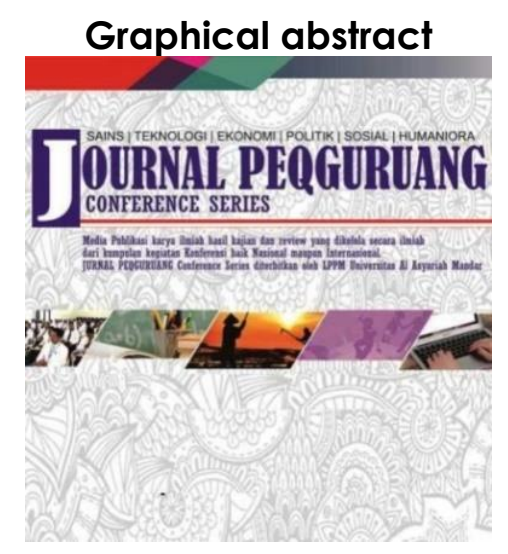

\section{EVALUASI KINERJA PELAYANAN PENGUJIAN KENDARAAN BERMOTOR JENIS ANGKUTAN BARANG PADA DINAS PERHUBUNGAN KABUPATEN MAMASA}

${ }^{1 *}$ Jonris. BK, ${ }^{2}$ Rustan, ${ }^{3}$ Masyhadiah

${ }^{123}$ Ilmu Pemerinahan, Fakultas Ilmu- ilmu Sosial dan Ilmu

Pemerintahan, Universitas Al Asyariah Mandar

Corresponding email

jonrisbk@gmail.com

rustam.irta17@gmail.com

masyhadiah22asharuddin@gmail.com

\begin{abstract}
This study uses descriptive qualitative research methods that aim to describe and describe events and phenomena that occur in the field and present data in a systematic, factual, accurate manner regarding the facts or phenomena that occur in the field. Data was collected by using observation, interview, and documentation techniques. Researchers used source triangulation to check the validity of research data. Data analysis in this study uses data reduction, data presentation, and drawing conclusions. The Service Technical Implementation Unit (UPTD) for Motor Vehicle Testing at the Mamasa Regency Transportation Service. The results of the study indicate that the Service Technical Implementation Unit (UPTD) Motor Vehicle Testing of the Mamasa Regency Transportation Service has implemented Responsiveness, Responsibility, and Transparency, but in its implementation it is still not going well. This can be seen from various things that are considered less in line with community expectations and the number of complaints from service users. The responsiveness indicator is considered still not optimal because it is less responsive in knowing mandatory needs and how to handle them. In the accountability indicator, it can be said that it has been implemented according to the legislation. Meanwhile, on the transparency indicator, it is considered that the performance has not been carried out well, this can be seen from the discovery of illegal levies
\end{abstract}

Keywords: Performance Evaluation, Employees, Services, Testing, Motor Vehicles

\begin{abstract}
Abstrak
Penelitian ini menggunakan metode penelitian deskriptif kualitatif yang bertujuan untuk menggambarkan dan mendeskripsikan peristiwa maupun fenomena yang terjadi di lapangan dan menyajikan data secara sistematis, faktual dan akurat. Pengumpulan data dilakukan dengan teknik observasi, wawancara, dan dokumentasi. Peneliti menggunakan triangulasi sumber untuk mengecek keabsahan data penelitian. Analisis data dalam penelitian ini menggunakan reduksi data, penyajian data, dan penarikan kesimpulan. Tujuan dari penelitian ini untuk mengetahui kinerja Unit Pelaksana Teknis Dinas (UPTD) Pengujian Kendaraan Bermotor pada Dinas Perhubungan Kabupaten Mamasa dalam memberikan pelayanan. Hasil penelitian menunjukkan bahwa Unit Pelaksana Teknis Dinas (UPTD) Pengujian Kendaraan Bermotor Dinas Perhubungan Kabupaten Mamasa telah menerapkan Responsivitas, Responsibilitas, dan Transparansi, akan tetapi dalam pelaksanaannya masih belum berjalan dengan baik. Hal ini terlihat dari berbagai hal yang dinilai kurang sesuai dengan harapan masyarakat dan banyaknya keluhan pengguna layanan. Pada Indikator responsivitas dinilai masih belum optimal karena kurang tanggap dalam mengetahui kebutuhan wajib dan cara dalam menanganinya. Pada Indikator responsibilitas dapat dikatakan sudah terlaksana sesuai peraturan perundang undangan. Sementara pada indikator transparansi, dianggap belum melaksanakan kinerja dengan baik, hal ini terlihat dari masih ditemukannya pungutan liar.
\end{abstract}

Kata Kunci : Evaluasi Kinerja, Pegawai, Pelayanan, Pengujian, Kendaraan Bermotor

Article history

DOI: https://dx.doi.org/10.35329/jp.v3i2.2217

Received : 11 September 2021 | Received in revised form : 19 Oktober 2021 | Accepted : 17 Novemeber 2021 


\section{PENDAHULUAN}

Ruang lingkup pelayanan publik meliputi berbagai macam aspek kehidupan masyarakat yang sangat luas dan kompleks. Kinerja organisasi yang baik sangat berpengaruh terhadap pelayanan publik yang mengutamakan kepuasan pelanggan (masyarakat). Namun, selama ini birokrasi belum mampu menunjukkan kondisi prima sesuai dengan harapan masyarakat. Kondisi tersebut merupakan salah satu faktor penyebab ketidak berhasilan kinerja birokrasi dalam upaya menuju Good Governance atau Publik Servis.

Organisasi publik merupakan penyelenggara pemerintahan dan pelayanan bagi warga Negara. Peran organisasi publik sangat sentral dalam sistem pemerintahan yang berhubungan langsung dengan masyarakat. Sehingga terciptanya suatu kinerja yang tinggi dalam organisasi publik perlu diupayakan agar penyelenggaraan pemerintahan dapat berjalan secara efektif, efisien dan responsif dalam memberikan pelayanan kepada masyarakat yang semakin kompleks. Peningkatan kualitas sumber daya pegawai menjadi sangat penting dan perlu dilakukan secara terencana, terarah dan berkesinambungan dalam rangka meningkatkan kemampuan dan profesionalisme. Sasaran dari pengembangan kualitas sumber daya pegawai adalah untuk meningkatkan kinerja operasional pegawai dalam melaksanakan tugas-tugas pemerintahan.(Nurfitrah, 2021)

Pentingnya diadakan pengujian kendaraan bermotor dimaksudkan agar kendaraan bermotor yang akan digunakan di jalan memenuhi persyaratan teknis dan layak jalan, termasuk persyaratan ambang batas emisi gas buang dan kebisingan yang harus dipenuhi. Pengujian kendaraan juga untuk mengurangi banyaknya kecelakaan yang disebabkan oleh kelayakan kendaraan bermotor yang tidak lolos uji.

Tujuan diselenggarakannya pengujian kendaraan bermotor tercantum pada Undang Undang No.14 tahun 1992 pasal 14 ayat 1 adalah sebagai berikut:

1. Untuk mengumpulkan data yang dapat digunakan untuk tertib administrasi, pengendalian kendaraan yang dioperasikan di Indonesia.

2. Mempermudah penyidikan pelanggaran atau kejahatan yang menyangkut kendaraan yang bersangkutan serta dalam rangka perencanaan, rekayasa dan manajemen lalu lintas dan angkutan jalan dan memenuhi kebutuhan data lainnya dalam rangka perencanaan pembangunan nasional.

3. Menjamin keselamatan, keamanan, dan ketertiban lalu lintas dan angkutan jalan maka pemeriksaan sebagaimana dimaksud dalam ayat ini dilakukan tidak pada satu tempat tertentu dan tidak secara terus menerus.

Tujuan dari penelitian ini adalah untuk mengetahui dan mendekripsikan "Evaluasi Kinerja Pegawai dalam Pelayanan Dinas Perhubungan Kabupaten Mamasa dalam Pengujian Kendaraan Bermotor Jenis Angkutan Barang”.

\section{METODE PENELITIAN}

\section{MetodePenelitian}

Jenis penelitian ini adalah kualitatif yang mempunyai sifat deskriptip dengan memberikan gambaran fakta yang mengacu kepada kejadian dalam penelitian ini tanpa membandingkan dengan menghubungkan variabel lainya dalam penelitian ini tentunya peneliti masih belum mempunyai contoh gambaran atau konsep penelitian ini.

Penelitian kualitatif adalah penelitian yang bermaksud untuk memahami fenomena tentang apa yang dialami oleh subjek penelitian misalnya prilaku, perinsip, motivasi tindakan, secara holistik dan dengan cara deskriptif dalam bentuk kata-kata dan bahasa, pada suatu konteks khusus yang alamiah dan dengan memanfaatkan berbagai metode ilmiah (Agusnadi, 2014). Pendekatan deskriptif bertujuan membuat deskripsi secara sistematis, faktual dan akurat tentang fakta-fakta dan sifat-sifat populasi atau objek tertentu (Heriawan, 2016).

Waktu Dan Tempat

Penelitian ini dilaksanakan di Kantor Dinas Perhubungan Kabupaten Mamasa, yang berlangsung pada bulan Febuari sampai Maret 2021.

\section{Informan Penelitian}

Teknik sampling yang digunakan dalam penelitian ini adalah purposive sampling yaitu teknik penentuan sampel dengan pertimbangan tertentu. Menurut (Amirullah, 2015) Purposive sampling merupakan salah satu bentuk dari convenience sampling yang dimana dalam teknik ini sampel dipilih berdasarkan penilaian atau pandangan dari para ahli berdasarkan tujuan dan maksud penelitian. Subjek yang dipilih menjadi sampel sesuai dengan ciri-ciri khusus yang dimiliki sampel. Informan yang ingin dijadikan sebagai sampel adalah pegawai Dinas Perhubungan bagian pengujian kendaraan bermotor dan masyarakat yang menjadi pengguna layanan.

Tabel 2. Tabel Informan

\begin{tabular}{|l|l|c|c|l|}
\hline No & \multicolumn{1}{|c|}{ Nama } & $\begin{array}{c}\text { Jenis } \\
\text { Kelamin }\end{array}$ & Usia & \multicolumn{1}{|c|}{$\begin{array}{c}\text { Jabatan } \\
\text { Pekerjaan }\end{array}$} \\
\hline 1 & Domina, S.Pd & L & 57 & $\begin{array}{l}\text { Kepala Dinas } \\
\text { Perhubungan }\end{array}$ \\
\hline 2 & Arjon Sumitro,ST & L & 46 & $\begin{array}{l}\text { Kabid Sarana } \\
\text { dan } \\
\text { Prasarana }\end{array}$ \\
\hline 3 & Tomas,S.Sos & L & 48 & $\begin{array}{l}\text { Kabid } \\
\text { Transportasi }\end{array}$ \\
\hline 4 & $\begin{array}{l}\text { Marselinus Pan, } \\
\text { S.Sos }\end{array}$ & L & 42 & $\begin{array}{l}\text { Kepala UPTD } \\
\text { Dinas } \\
\text { Perhubungan }\end{array}$ \\
\hline 5 & $\begin{array}{l}\text { Pieter Arruan } \\
\text { Banga,S.Sos }\end{array}$ & L & 32 & $\begin{array}{l}\text { Petugas } \\
\text { Penguji }\end{array}$ \\
\hline 6 & Demianus & L & 27 & $\begin{array}{l}\text { Petugas } \\
\text { Pendaftaran }\end{array}$ \\
\hline 7 & Mashendro & L & 24 & $\begin{array}{l}\text { Supir truk } \\
\text { angkutan } \\
\text { barang }\end{array}$ \\
\hline 8 & Arwanto & L & 29 & $\begin{array}{l}\text { Supir truk } \\
\text { angkutan } \\
\text { barang }\end{array}$ \\
\hline 9 & Genggong & L & 27 & $\begin{array}{l}\text { Supir truk } \\
\text { angkutan } \\
\text { barang }\end{array}$ \\
\hline 10 & Pampang Bone & L & $\begin{array}{l}\text { Supir truk } \\
\text { angkutan }\end{array}$ \\
\hline
\end{tabular}




\begin{tabular}{|l|l|l|l|l|}
\hline & & & & barang \\
\hline 11 & Tadibali & L & 31 & $\begin{array}{l}\text { Supir truk } \\
\text { angkutan } \\
\text { barang }\end{array}$ \\
\hline 12 & Yunus & L & 35 & $\begin{array}{l}\text { Supir truk } \\
\text { angkutan } \\
\text { barang }\end{array}$ \\
\hline
\end{tabular}

\section{Instrumen Penelitian}

Dalam hal ini peneliti menggunakan instrumen penelitian yakni berinteraksi secara langsung dengan responden penelitian, bahkan untuk penggalian data yang menuntut partisipasi peneliti secara terbatas keterlibatan peneliti menjadi suatu keharusan. Untuk teknik penelitian yang digunakan untuk menggali data adalah Observasi, Wawancara, Dokumentasi.

\section{Teknik Pengumpulan Data}

Teknik pengumpulan data merupakan langkah yang paling strategis dalam penelitian, karena tujuan utama dari penelitian adalah mendapatkan data (Sugiyono, 2007: 62). Teknik pengumpulan data yang digunakan dalam penelitian ini adalah:

1. Observasi

Observasi yaitu pengamatan secara langsung di lokasi penelitian guna memperoleh keterangan data yang lebih akurat mengenai hal-hal yang diteliti.

2. Wawancara

Wawancara yaitu suatu cara untuk mendapatkan dan mengumpulkan data melalui tanya jawab dan dialog atau diskusi dengan informan yang dianggap mengetahui banyak tentang obyek dan masalah penelitian.

3. Dokumentasi

Dokumentasi adalah pencatatan berbagai arsip dan dokumentasi yang ada hubungannya dengan penelitian.

\section{Teknik Analisis Data}

Dalam melakukan analisis data pada penelitian ini, peneliti mengacu pada tahapan teknik analisis data menurut Miles dan Huberman dalam Herdiansyah, Haris (2010: 164) yaitu:

1. Pengumpulan data.

Pada tahap ini peneliti melakukan proses pengumpulan data dengan menggunakan teknik pengumpulan data yang telah ditentukan sejak awal.

2. Reduksi data (Data reduction).

Data yang telah diseleksi akan diolah dengan cara mereview dan menyatukan serta memformulasikan data, sehingga data yang sama dari hasil interview dan data non interview dapat dikategorisasikan untuk memudahkan informasi dalam proses analisis data.

3. Penyajian data (Data display).

Proses penyajian data dilakukan melalui penyusunan dan pengkategorisasian data yang diperoleh dari pengolahan data, sehingga penyatuan data tersebut dihubungkan dengan pola yang terdapat pada hasil temuan di lapangan yang selanjutnya akan di analisa oleh peneliti dengan berdasarkan teori yang relevan.

4. Tahap penarikan kesimpulan dan verifikasi
(Conclusion drawing and verification).

Langkah terakhir dalam analisis data kualitatif menurut Miles dan Huberman adalah penarikan kesimpulan dan verifikasi.

\section{HASIL DAN PEMBAHASAN HASIL PENELITIAN}

Memberikan Pelayanan yang optimal dapat diwujudkan dalam suatu bentuk kinerja organisasi dengan mengukur kinerja pelayanan publik dengan menggunakan indikator-indikator penilaian sebagai ukuran dari keberhasilan suatu organisasi pemerintah.

Adapun indikator untuk mengevaluasi kinerja Unit Pelaksana Teknis Dinas Pengujian Kendaraan Bermotor Dinas Perhubungan Kabupaten Mamasa yaitu responsivitas, responsibilitas, dan transparansi dengan penggambaran fakta lapangan sesuai dengan observasi dan wawanacara beberapa narasumber dengan hasil penelitian sebagai berikut:

\section{a. Responsivitas}

Responsivitas merupakan kemampuan sebuah organisasi mengetahui apa yang dibutuhkan oleh masyarakat, mampu menyusun agenda dan prioritas dalam memberikan pelayanan serta mengembangkan program-program pelayanan sesuai dengan kebutuhan dan aspirasi masyarakat. Dalam artian bahwa responsivitas mengarahkan pada keselarasan antara kegiatan pelayanan yang dibutuhkan dan aspirasi masyarakat dengan program-program pelayanan publik.

UPTD Pengujian Kendaraan Bermotor Dinas Perhubungan Kabupaten Mamasa telah merespon berbagai keluhan tersebut demi perbaikan pelayanan, sebagaimana yang diungkapkan Kepala Dinas Perhubungan Bapak Domina, S.Pd. dalam kutipan wawancaranya sebagi berikut :

"pelayanan yang kami berikan sudah sesuai dengan prosedur, ini terlihat dimana kurangnya complain dari masyarakat mengenai pelaksanaan uji kelayakan bermotor di dinas perhubungan, meskipun kita menyadari bahwa pada kenyataannya masih ada hal yang masih harus di tingkatkan" (Wawancara, 15 Maret 2021)

Pelayanan Pengujian Kendaraan Bermotor telah dilakukan sesuai dengan SOP pelayanan uji kendaraan, hal tersebut juga diungkapkan Petugas penguji Bapak Pieter Arruan Banga,S.Sos, dalam kutipan wawancaranya sebagi berikut:

"Sudah ada kesesuaian dengan panduan pengujian atau SOP, adapun jika ada keluhan atau aspirasi dari pemilik kendaraan maka petugas uji kelayakan berusaha memberi solusi" (Wawancara 15 Maret 2021)

Dari pernyataan diatas dapat dikatakan bahwa pelayanan yang diberikan oleh UPTD Pengujian Kendaraan telah dilaksanakan sesuai dengan tahapan pelaksanaan, adapun keluhan tidak bisa lepas dari pelayanan publik yang diberikan. UPTD Pengujian Kendaraan Bermotor Dinas Perhungan juga telah menerima berbagai keluhan masyarakat. b. Responsibilitas

Diharapkan dengan Resposibilitas dapat menciptakan pelaksanaan pengujian kendaraan bermotor oleh UPTD Pengujian Kendaraan 
Bermotor Dinas Perhubungan Kabupaten Mamasa yaitu penyelenggaraannya yang sesuai dengan prosedur, peraturan, kewenangan yang dipertanggungjawabkan dengan tetap memperhatikan responsivitas terhadap publik.

Terkait hal tersebut, Kepala Dinas Perhubungan Bapak Domina, S.Pd menjelaskan dalam kutipan wawancaranya sebagai berikut

"mekanisme pengujian bermotor di Kabupaten Mamasa dimulai dari pendaftaran dengan menyertakan semua persyaratan yang diminta seperti STNK, Buku Uji Kendaraan dll, kemudian melakukan pembayaran biaya retribusi selanjutnya dilakukan verifikasi kendaraan, tahap berikutnya pemeriksaan dan pengujian kendaraan, dan terakhir pengesahan. (Wawancara, 15 Maret 2021)

Pernyataan diatas didukung penjelasan Kepala Bidang Transportasi Bapak Thomas, S.Sos dalam kutipan wawancaranya sebagai berikut:

"jadi pemilik kendaraan ini harus melengkapi berkas yang telah ditentukan, penetapan surat ketetapan retribusi daerah (SKRD), uji teknis kendaraan, uji kelayakan pada kendaraan, analisis dan penetapan hasil uji kendaraan, jika kendaraan lulus uji lalu di tetapkan pengesahan hasil lulus uji dan jika kendaraan tidak lulus uji maka pemilik kendaraan dapat melakukan banding hasil uji atau uji ulang kendaraan. (Wawancara, 15 Maret 2021)

Penerapan aturan-aturan tersebut dilaksanakan sesuai pedoman yang telah ditetapkan, dalam menginplementasikan aturan tersebut pihak UPTD Pengujian Kendaraan Bermotor diberikan kewenangan untuk melaksanakannya disesuaikan dengan kondisi di lapangan. Hal ini diungkapkan oleh Kepala UPTD Pengujian Kendaraan Bermotor Dinas Perhubungan Kabupaten Mamasa Bapak Marselinus, S.Sos

\section{c. Transparansi}

Dalam proses pelayanan publik, memberikan informasi mengenai berbagai hal kegiatan maupun aktivitas harus selalu diinformasikan secara terbuka agar dapat diakses oleh masyarakat. Indikator transparansi digunakan dalam penelitian ini untuk melihat seperti apa UPTD Pengujian Kendaraan Bermotor Dinas Perhubungan Kabupaten Mamasa dalam memberikan informasi secara terbuka mengenai proses pelayanan dengan tujuan agar masyarakat pengguna layanan lebih mudah mendapatkan informasi pelayanan, diketahui dan dipahami oleh masyarakat pengguna layanan tersebut. Hal tersebut diketahui dalam wawancara dengan salah satu informan wajib uji Bapak Tadibali dalam kutipan wawancaranya sebagai berikut:

"ya, petugas memberikan penjelasan tentang proses uji yang berlangsung. Cukup aktif memberikan jawaban ketika kami bertanya, mereka menjelaskan semua pertanyaan yang saya ajukan. Jadi mereka memberi informasi secara langsung dan juga melalui papan informasi di Kantor Pengujian Kendaraan" (Wawancara, 17 Maret 2021)

Lebih lanjut wajib uji Bappak tadibali mengemukakan terkait biaya tarif restribusi dalam kutipan wawancaranya sebagai berikut: "saya liat terbukaji, didepan loket ada informasi biaya-biaya dan di kwitansi yang diberikan juga tertera penjelasan biaya-biaya apa saja yang telah dibayarkan. (Wawancara, 17 Maret 2021)

Dari hasil wawancara diatas maka dapat dikatakan bahwa kejelasan informasi maupun tarif retribusi sudah dilaksanakan oleh UPTD walaupun belum maksimal sesuai keinginan masyarakat, namun komunikasi, koordinasi dan kepercayaan wajib uji terhadap UPTD bisa dikatan sudah berjalan dengan baik

\section{d. Faktor Pendukung Kinerja}

Pelaksanaan pengujian kendaraan bermotor yang dilakukan oleh UPTD Pengujian Kendaraan Bermotor Dinas Perhubungan Kabupaten Mamasa tidak terlepas dari adanya faktor pendukung kinerja. Berdasarkan hasil wawancara dengan berbagai informan terutama pegawai UPTD Pengujian Kendaraan Bermotor Kabupaten Mamasa dalam proses pelaksanaan pengujian kendaraan memiliki faktor-faktor pendukung kinerja antara lain yaitu :

1. Faktor Sarana dan Prasarana

Hal terpenting pertama yang menjadi faktor pendukung kinerja adalah Sarana dan prasarana sehingga kinerja bisa menghasilkan kinerja yang maksimal dan optimal. Seperti yang diungkapkan Kepala Bidang Sarana dan Prasarana Bapak Arjon Sumitor, ST dalam kutipan wawancaranya sebagai berikut:

"meski masih terbatas namun sarana dan prasarana atau alat teknis pengujian yang kami miliki sejauh ini baik dan lumayan, sudah bisa membuat pelayanan kita memuaskan wajib uji walaupun masih ada beberapa yang sangat perlu dibenahi dan ditambah" (15 Maret 2021)

\section{Faktor Dukungan dari Pimpinan}

Dalam proses peningkatan kinerja pelayanan sangat dibutuhkan dukungan dari pemimpin. Dengan adanya dukungan dari pemimpin maka diharapkan semangat dan kekompakan dari pegawai dapat terjaga dengan memberikan keinrja terbaik pada bidangnya masing-masing. Dukungan itu bisa berbentuk pemberian penghargaan kepada pegawai berprestasi maupun sekedar perlakuan yang baik atau kata-kata motivator dari pemimpin. Terkait hal tersebut, Kepala Bidang UPTD Pengujian Kendaraan Bermotor Dinas Perhubungan Kabupaten Mamasa Bapak Marselinus, S.Sos mengungkapkan bahwa:

"ya inikan pegawai kita terdiri dari berbagai macam karakter, jadi yang bisa menyatukan mereka itu adalah pimpinannya. Nah kita selalu berusaha menjaga semangat dan kekompakan mereka, memberi mereka dukungan agar tetap maksimal dalam bekerja dan memberikan pelayanan yang terbaik kepada masyarakat, itu yang kami terapkan disini" (Wawancara 15 Maret 2021)

3. Faktor Sistem Informasi Manajemen

Faktor pendukung selanjutnya adalah Sistem informasi manajemen (SIM), SIM mampu mempengaruhi kinerja dalam memberikan pelayanan publik yang optimal, dalam hal ini sistem informasi manajemen yang berhubungan dengan pengelolaan data base yang digunakan 
dalam meningkatkan kinerja organisasi. Sebagaimana yang diungkapkan Kepala UPTD Pengujian Kendaraan Bermotor Marselinus, S.Sos dalam kutipan wawancaranya sebagai berikut:

"pendataan kendaraan ini masuk dalam mekanisme atau proses pengujian pra uji kendaraan. Jadi setiap kendaraan baru yang diujikan pemiliknya, petugas kami selalu melakukan pendataan kendaraan terlebih dahulu yang disesuaikan dengan spesifikasi kendaraan tersebut, agar semua kendaraan yang ada di Kabupaten Mamasa kita punya data-datanya", (Wawancara 15 Maret 2021)

\section{e. Faktor Penghambat Kinerja}

Selain adanya faktor pendukung kinerja, ada juga faktor yang menghambat kinerja bisa tidak berjalan maksimal. Dari hasil penelitian diatas maka dapat diidentifikasi faktor penghambat apa saja yang muncul dalam pengujian kendaraan bermotor di UPTD Pengujian Kendaraan Bermotor di Kabupaten Mamasa.

Dapat disimpulkan dalam penelitian ini bahwa ada dua faktor terbesar yang menghambat kinerja pelayanan yaitu diakibatkan faktor internal dan faktor eksternal.

\section{PEMBAHASAN}

Evaluasi kinerja maupun penilaian kinerja pelayanan publik sangat penting dilakukan untuk mengetahui atau mengukur seperti apa tingkat pencapaian keberhasiannya sehingga dapat diketahui sejauh mana instansi pemerintah tersebut telah bekerja untuk masyarakat. Evaluasi kinerja atau penilaian kinerja sebuah organisasi publik merupakan suatu kegiatan yang digunakan sebagai ukuran keberhasilan suatu organisasi dalam mencapai misinya.

Adapun pembahasan dari hasil penelitian yang peneliti lakukan di Unit Pelaksana Teknis Dinas Pengujian Kendaraan Bermotor Dinas Perhubungan Kabupaten Mamasa, sebagai berikut:

\section{a. Responsivitas}

Indikator Responsivitas yang terapkan UPTD Pengujian Kendaraan Bermotor Dinas Perhubungan Kabupaten Mamasa, bisa dilihat dari pemberian pelayanan yang dilakukan telah mengukiti dengan Standar Opersional Prosedur pengujian kendaraan. Dengan mengikuti SOP maka alur pendaftaran menjadi lebih teratur. Pelaksanaan pengujian kendaraan bermotor oleh UPTD Pengujian Kendaraan Bermotor Dinas Perhubungan Kabupaten Mamasa telah dilaksanakan sesuai dengan tahapan pelaksanaan. Namun keluhan dari masyarakat tidak bisa dihindari oleh suatu organisasi pelayanan publik termasuk kantor UPTD Pengujian Kendaraan Bermotor Dinas Perhubungan Kabupaten Mamasa.

Berbagai keluhan masyarakat ditemukan dalam penelitian ini, diantaranya minimnya fasilitas pengujian kendaraaan bermotor, tidak adanya bengkel yang disediakan oleh UPTD pengujian kendaraan bermotor sehingga ketika kendaraan pengguna layanan dianggap belum standar karena adanya alat kendaraan yang bermasalah atau perlu dilakukan pergantian sementara tempat pengujian kendaraan dengan pusat penjualan suku cadang jarak tempuhnya terbilang jauh.
Keluhan-keluhan tersebut adalah hak pengguna layanan dan pihak UPTD Pengujian Kendaraan Bermotor seharusnya menindak lanjuti keluhan tersebut. Namun dari hasil penelitian ditemukan fakta bahwa tidak ada bagian khusus di UPTD Pengujian Kendaraan Bermotor yang khusus mengelola aduan tersebut, hal ini diakibatkan minimnya SDM yang ada di UPTD sehingga beberapa pegawai harus merangkap pekerjaan yang seharusnya dilakukan masing-masing bagian.

Hal tersebut menyebabkan pelayanan yang diberikan masih belum maksimal sementara dijelaskan dalam Undang-Undang nomor 76 tahun 2013 tentang pelayanan publik, dikatakan bahwa setiap organisasi pelayanan publik diharuskan memiliki pengelolaan pengaduan.

\section{b. Responsibilitas}

Levine dalam Dwiyanti (2008: 143) mengemukakan responsibility atau responsibiltas atau tanggungjawab adalah suatu ukuran yang menujukkan seberapa jauh proses pemberian pelayanan publik dilakukan sesuai dengan prinsipprinsip atau ketentuan-ketentuan administrasi dan organisasi yang benar dan telah ditetapkan. Dalam memberikan pelayanan kepada publik memiliki berbagai prinsip-prinsip maupun ketentuanketentuan administrasi organisasi yang telah ditetapkan untuk menjadi pedoman dan penujnag kualitas tanggungjawab petugas pelayanan terhadap kinerja dalam memberikan pelayanan.

Hasil penelitian menunjukkan bahwa pihak UPTD Pengujian Kendaraan Bermotor Kabupaten Mamasa, merujuk pada Standar Operasional Prosedur (SOP) UPTD Pengujian Kendaraan Bermotor Kabupaten Mamasa, mekanisme atau pelaksanaan pengujian kendaraan bermotor diawali dari pendaftaran kendaraan di loket pendaftaran, dengan melengkapi persyaratan atau melampirkan STNK, Buku Uji Kendaraan untuk kendaraan yang pernah diuji sebelumnya, Surat Keterangan Perubahan Bentuk Kendaraan bagi kendaraan yang khusus menggunakan keroseri atau bak baru, untuk kendaraan umum wajib melampirkan Surat Ijin Usaha Ijin Usaha dan Surat Ijin Trayek, Surat Keterangan Restribusi Daerah atau SKRD, Laporan Hasil Pemeriksaan Kendaraan Bermotor, selanjutnya kendaraan akan didata berdasarkan klasifikasi, kemudian melakukan pembayaran restribusi selanjutnya kendaraan akan melalui pengujian oleh penguji dengan berbagai tahapan yang akhirnya jika dinyatakan lulus uji maka akan ditetapkan pengesahan dan jika hasilnya tidak lulus, wajib uji kendaraan bisa melakukan banding hasil uji atau ikut uji ulang kendaraan.

Maka dapat disimpulkan bahwa penerapan responsibilitas telah dilakukan oleh UPTD Pengujian Kendaraan Bermotor Dinas Perhubungan Kabupaten Mamasa, hal ini terlihat dari pelaksananan pengujian kendaraan bermotor yang dilakukan UPTD Pengujian Kendaraan Bermotor Dinas Perhubungan Kabupaten Mamasa dinilai cukup baik. Dalam melaksanakan peran dan tugasnya UPTD Pengujian Kendaraan Bermotor Dinas Perhubungan Kabupaten Mamasa telah sesuai dengan peraturan. 


\section{c. Transparansi}

Ukuran transparansi atau keterbukaan dalam memberikan informasi dan hal lain yang terkait mekanisme pengujian kendaraan bermotor menginformasikan secara terbuka sehingga lebih mudah dipahami dan diketahui masyarakat pengguna layanan. Adapun informasi yang disampaikan sebagai bentuk transparansi pelaksanaan kegiatan berupa penyelenggaraan pelayanan, mekanisme atau prosedur, persyaratan administrasi maupun teknis dalam pelayanan serta tarif restribusi yang harus dibayar masyarakat pengguna layanan.

Adapun Transparansi yang diterapkan oleh UPTD Pengujian Kendaraan Bermotor Dinas Perhubungan Kabupaten Mamasa dengan memberikan informasi secara lisan kepada pemilik kendaraan dan papan informasi yang dipajang di tembok ruangan pengujian kendaraan. Komunikasi langsung juga menjadi unsur dalam memberikan informasi kepada pemilik kemdaraan atau pengguna layanan, hal ini dianggap akan lebih mudah memberikan pemahaman kepada masyarakat pemilik kendaraan karena menjelaskannya lebih detail sehingga akan menciptakan kepercayaan pemilik kendaraan kepada petugas penguji.

\section{d. Faktor Pendukung}

Dalam penelitian ini di fokuskan pada tiga indikator faktor pendukung yang dianggap bisa meningkatkan kinerja UPTD Pengujian Kendaraan Bermotor Dinas Perhubungan Kabupaten Mamasa jika mampu dimaksimalkan sehingga terwujudnya kepuasan masyarakat dapat tercapai. Adapun ketiga indikator yang dimaksud yaitu a. sarana dan prasarana, b. dukungan dari pimpinan, dan c. sistem informasi manajemen.

Dari hasil penelitian dapat dilihat bahwa faktor pendukung dengan menggunakan tiga indikator tersebut dinilai cukup mendukung kinerja pelayanan dan telah digunakan dengan maksimal di UPTD Pengujian Kendaraan Bermotor Dinas Perhubungan Kabupaten Mamasa.. Seperti sarana dan prasarana yang digunakan walaupun masih terbatas dan masih menggunakan alat yang telah lama namun dengan kinerja dan kemampuan memaksimalkan alat teknis dengan baik sehingga proses penyelesaian tetap berjalan dengan lancar. Alat bantu dalam melaksanakan proses adminitrasi ditiap-tiap bagian administrasi juga telah disediakan sehingga alur penyelesaian administrasi bisa berjalan dengan optimal. Pengadaan seperti CCTV untuk memantau kinerja pegawai sekaligus untuk menimalisir praktek pungatan liar juga telah sediakan oleh UPTD Pengujian Kendaraan Bermotor Dinas Perhubugan Kabupaten Mamasa.

\section{e. Faktor Penghambat}

Jika ada faktor pendukung maka akan ada faktor penghambat. Dalam penelitian ini ada 2 faktor yang dianggap menghambat peningkatan kinerja UPTD Pengujian Kendaraan Bermotor Dinas Perhubungan Kabupaten Mamasa yaitu faktor internal dan faktor eksternal. Faktor internal sendiri terdiri dari 2 penyebab yaitu terbatasnya anggaran dan kurangnya sumber daya manusia atau tenaga teknis, sementara untuk faktor eksternal juga terdiri dari 2 penyebab yaitu kurangnya pemahaman masyarakat dan kesadaran masyarakat untuk menguji kendaraannya.

\section{SIMPULAN}

Berdasarkan hasil penelitian dapat disimpulkan bahwa kinerja UPTD Pengujian Kendaraan Bermotor Dinas Perhubungan Kabupaten Mamasa telah cukup baik, meskipun masih ada beberapa bagian yang dinilai tidak sesuai dengan keinginan masyarakat pemilik kendaraan wajib uji, hal tersebut bisa digambarkan dari indikator responsivitas, responsibilitas, dan transparansi sebagai berikut :

1. Responsivitas

Responsivitas UPTD Pengujian Kendaraan Bermotor Dinas Perhubungan Kabupaten Mamasa dalam memberikan pelayanan kepada wajib uji belum berjalan sesuai keinginan masyarakat pengguna layanan wajib uji atau masih kurang maksimal.

2. Responsibilitas

Responsibilitas UPTD Pengujian Kendaraan Bermotor Dinas Perhubungan Kabupaten Mamasa dalam kinerja pelayanan pengujian kendaraan dinilai cukup baik dalam melaksanakan peran dan fungsinya dan sesuai dengan peraturan yang berlaku.

3. Transparansi

Wujud dari keterbukaan informasi adalah Transparansi informasi dan pengumuman mengenai mekanisme, prosedural, serta berbagai persyaratan administrasi dalam melakukan pengujian kendaraan bermotor oleh UPTD Pengujian Kendaraan Bermotor Dinas Perhubungan Kabupaten Mamasa sudah cukup baik, hal ini terlihat dari keterbukaan komunikasi antara pihak UPTD dengan masyarakat wajib uji terjalin dengan baik.

\section{Saran}

Berdasarkan kesimpulan diatas dapat diketahui bahwa kinerja UPTD Pengujian Kendaraan Bermotor Dinas Perhubungan Kabupaten Mamasa dalam pengujian kendaraan bermotor sudah cukup baik, namun masih ada beberapa keluhan dan persoalan yang belum teratasi sehingga peneliti memberikan beberapa saran atau rekomendasi sebagai berikut ; Menjalin komunikasi yang baik dengan pihak pemerintah atau instansi terkait sehingga jalan menuju tempat pengujian kendaraan bermotor yang rusak parah bisa dibenahi, secara internal dengan mengundang pemateri sehingga dapat memanilisir pengeluaran dana yang memang anggaran untuk UPTD sangat terbatas, Memberikan pemahaman kepada masyarakat dengan turun langsung ke masyarakat khususnya kepada masyarakat pengguna layanan pengujian kendaraan wajib uji sehingga kesalapahaman yang berkembang di masyarakat dapat diatasi.

\section{DAFTAR PUSTAKA}

Agusnadi, A. (2014). Efektivitas Pemberian Sanksi Bagi Siswa Pada Pelanggaran Tata Tertib Di Smp 2 Kapuas Timur Kabupaten Kapuas. Jurnal Pendidikan Kewarganegaraan, 4(8), 121400.

Amirullah. (2015). Populasi dan Sampel. 1-14. https://doi.org/10.1007/BF00353157 
Dwiyanto, A. (2015). Manajemen Pelayanan Publik; Peduli, Inklusif dan Kolaboratif. Yogyakarta : Gadjah Mada University Press.

Heriawan, S. (2016). Pola Komunikasi Kelompok Pada Komunitas Scooter "Vespa" Dalam Menjalin Hubungan Solidaritas (Studi Deskriptif Kualitatif Pada Komunitas Ikatan Scooter Wonogiri di Wonogiri) NASKAH. Naskah Publikasi, 53 (9), 12.

Herdiansyah, Haris. 2010. Metode Penelitian Kualitatif untuk IImu-ilmu Sosial. Jakarta: Salemba Humanika.

Nurfitrah, 2021 Efektivitas Kinerja Pegawai Dalam Pelayanan Pembuatan E-Ktp Pada Dinas Kependudukan Dan Catatan Sipil Kabupaten Polewali Mandar, 2021 Mitzal (Demokrasi, Komunikasi Dan Budaya): Jurnal Ilmu Pemerintahan Dan Ilmu Komunikasi.

Sugiyono. 2007. Metode Penelitian Kuantitatif Kualitatif dan R\&D. Bandung: Alfabeta.

Perundang - undangan

Undang Undang No.14 tahun 1992 pasal 14 ayat 1

Peraturan Daerah Nomor 5 tahun 2016 Tentang Struktur Organisasi Perangkat Daerah Lingkup Pemerintah Mamasa

Peraturan Bupati Mamasa Nomor 32 Tahun 2016, tentang Struktur Organisasi Dinas Perhubungan Kabupaten Mamasa Maka Dinas Perhubungan Kabupaten Mamasa 